At the Heart of the Empire 



\section{At the Heart of the Empire}

Indians and the

Colonial Encounter in

Late-Victorian Britain

Antoinette Burton

University of California Press

Berkeley / Los Angeles / London 
This book is a print-on-demand volume. It is manufactured using toner in place of ink. Type and images may be less sharp than the same material seen in traditionally printed University of California Press editions.

University of California Press

Berkeley and Los Angeles, California

University of California Press, Ltd.

London, England

C1998 by the Regents of the University of California

Some parts of this book have been published previously in somewhat different form.

Chapter 2: "Colonial Encounters in Late-Victorian England: Pandita Ramabai at

Cheltenham and Wantage, 1883-86", Feminist Review 49 (spring 1995): 29-49.

Chapter 4: "The Wanderings of a "Pilgrim Reformer": Behramji Malabari in Late-

Victorian London", Gender and History 8, no. 2 (August 1996): 175-96; and "Making a

Spectacle of Empire: Indian Travellers in Fin-de-Siècle London", History Workshop

Journal 42 (1996): 96-II7.

\section{Library of Congress Cataloging-in-Publication Data}

Burton, Antoinette, 196I-. At the heart of the empire: Indians and the colonial encounter in late-Victorian Britain / Antoinette Burton.

p. $\mathrm{cm}$.

Includes bibliographical references and index.

ISBN 0-520-20958-3 (alk. paper)

1. East Indians-Great Britain-History-19th century. 2. Malabari, Behramji M. (Behramji Merwanji), I853-1912-Journeys-Great

Britain. 3. Ramabai Sarasvati, Pandita, 1858-1922-Journeys-Great

Britain. 4. Sorabji, Cornelia-Journeys-Great Britain.

s. Imperialism-Great Britain-History-19th century. 6. Great

Britain-Social life and customs-19th century. 7. Great Britain-

History-Victoria, 1837-1901. 8. Great Britain-Relations-

India. 9. India-Relations-Great Britain. Io. Great Britain-

Ethnic relations. I. Title.

DA125.S57 B87 1998

305.891'41104I'09034-dc21

96-29617

Manufactured in the United States of America

The paper used in this publication meets the minimum requirements of American National Standard for Information SciencesPermanence of Paper for Printed Library Materials, ANSI Z39.48I984. 
To my father and my mother

for whom there'll always be an England 

"England," said Christophine... "You

think there is such a place?"

Jean Rhys, Wide Sargasso Sea (1966) 
